\title{
Determinants of rainwater harvesting technology (RWHT) adoption for home gardening in Msinga, KwaZulu-Natal, South Africa
}

\author{
Lloyd James S Baiyegunhi ${ }^{*}$ \\ 'SAEES - Discipline of Agricultural Economics, University of KwaZulu-Natal, P. Bag X01, Scottsville 3209, Pietermaritzburg, South Africa
}

\begin{abstract}
Home gardening is extremely important for resource-poor households that have limited access to production inputs. However, in South Africa attempts to implement home garden programmes often fail to improve food security of the poor due to water scarcity. Rainwater harvesting technology (RWHT) has been used to supplement the conventional water supply systems, but its potential has not been fully exploited. An understanding of the factors influencing the adoption of improved technologies is therefore critical to successful implementation of agricultural development programmes. This study evaluated the determinants of farmers' decisions to adopt rainwater harvesting technology (RWHT) in rural Msinga, KwaZulu-Natal Province, South Africa, using a binary logistic regression model based on a household survey of 180 rural home gardeners. The result of the logistic regression model showed that gender, age, education, income, social capital, contact with extension agent and perception/attitude towards RWHT are statistically significant in explaining farmers' adoption of RWHT in the study area. Implications for agricultural and rural development policy were discussed.
\end{abstract}

Keywords: home gardening, rainwater harvesting technology, adoption, logistic regression, South Africa

\section{INTRODUCTION}

For centuries, small plots of land near homesteads have been used as home gardens, which have been an integral component of family farming and local food systems (Odebode, 2006; Galhena et al., 2013). Home gardens are found in both rural and urban areas in predominantly small-scale subsistence agricultural systems (Nair, 1993). This is to facilitate households' direct access to a diversity of nutritionally-rich foods, which include roots, tubers, green leafy vegetables, condiments, nuts, legumes, fruits, spices, herbs, ornamental and medicinal plants and livestock products (Payre et al., 2006). Home gardening has been documented as an important supplemented source contributing to food and nutritional security and livelihoods, and remains the most important method of food production for the majority of people in developing countries including South Africa (HSRC, 2003; Action Aid, 2005). The benefits of home gardening include enhancement of food and nutritional security; improvement of health (as plants are an important source of medicine for humans and livestock); uplifting the socioeconomic status of women; preservation of indigenous knowledge and building integral societies; contribution to income generation, improved livelihoods, and household economic welfare, as well as promoting entrepreneurship and rural development; and conservation of biodiversity and natural resources (Galhena et al., 2013).

The fact that home production is less cost-intensive and requires fewer inputs and investment makes home gardening extremely important for resource-poor households that have limited access to production inputs (Galhena et al., 2013). However, numerous attempts in South Africa to implement home garden programmes have often failed to improve food security of the

\footnotetext{
To whom all correspondence should be addressed.

잉 +27 33260 5437; e-mail: BaiyegunhiL@ukzn.ac.za

Received 29 April 2014; accepted in revised form 26 November 2014.
}

poor (Moorhead and Wilmer, 2001). One of the major factors affecting the success of home gardening is water scarcity. Water shortage for agriculture has increasingly been recognised as a major constraint to improving the lives of the rural poor. It affects rain-fed crop production and directly threatens the livelihood of millions of people, particularly in developing countries, and especially in Sub-Saharan Africa (Vink and Kirsten, 2003; Owei and Hachum, 2006). Water has become an important component of rural livelihood programmes being established in Southern Africa (Vink and Kirsten, 2003). South Africa is a water-scarce country with an average annual rainfall of $500 \mathrm{~mm}$, approximately $60 \%$ of the world average (DWAF, 1994). Only a narrow region along the south-eastern coastline receives good rainfall, with the greater part of the interior and western part of the country being arid or semi-arid, $65 \%$ of the country receives less than $500 \mathrm{~mm}$ per annum, which is usually regarded as the minimum for dryland farming, while $21 \%$ receives less than 200 mm per year (DWAF, 1994). According to Otieno and Ochieng (2004), of the 19 South African Water Management Areas (catchment based) in 2004, 11 experienced water deficit, where the requirements for water exceed its availability.

In South Africa, agriculture involves large numbers of people and is generally the largest user of rainwater, about $70 \%$ of the rainfall is used to produce food, natural fibres and forestry products (Department of Health, 2006). Water scarcity in South Africa places considerable strain on rural communities who directly rely on rainfall to sustain their livelihoods, especially poor communities living in low-income houses with little access to services and resources (Bulcock and Schulze, 2011). Irregularities in timing and distribution of rainfall often leave these communities without access to water for the most basic daily needs, including farming activities (Bulcock and Schulze, 2011)

Increasing the crop water productivity in smallholder farming is important since productivity is often low but has large potential to be enhanced (Molden, 2007). More efficient utilisation of available water resources has the potential to 
contribute towards alleviation of water scarcity, and is essential for improved food security, especially in rural areas where the majority of the food-insecure population depend on rain-fed agriculture for their livelihood (Liu et al., 2008). The strategies to manage water efficiently and achieve food and livelihood security are numerous and of varied success (Yang and Zehnder, 2007). Over the years and especially throughout sub-Saharan Africa, indigenous knowledge systems have adopted various ways of collecting and storing rainwater for later use (Mbilinyi et al., 2005; Rockstrom, 2000); rainwater harvesting technology (RWHT) is the most common of these.

Rainwater harvesting, defined as the concentration, collection and storage (in different structures or in the soil) of rainwater for use either on-site or at different location, immediately or at a later time (Boer, 1994; Siegert, 1994). It is where rainwater is collected from rooftops, courtyards and similar compacted or treated surfaces, stored in underground tanks (UGTs) or above-ground tanks (AGTs) and used for domestic purposes, garden watering and small-scale productive activities (Mwenge-Kahinda et al., 2007). Rainwater harvesting can contribute towards more efficient use of water resources in rural areas (Oweis, 1999) and can greatly increase agricultural productivity, improve food security and alleviate poverty. Rainwater harvesting technology (RWHT) can be implemented to alleviate temporal water supply problems and supplement conventional water supply systems, as demand is increasingly growing (Mwenga-Kahinda, et al., 2005). However the full potential of this type of water supply has not been fully exploited in South Africa, especially in the rural areas. About $72 \%$ of South Africa's poor, which constitute the majority of the population, live in rural areas. These areas are mostly semi-arid to arid, and are marginal for crop production, except for a small proportion under irrigation (Baipheti et al., 2006). In South Africa, the combined area of backyard gardens of rural homesteads amounts to 200000 ha, an amount which doubles the area under irrigation (NDA, 2007). This means that the potential impact of home gardens on household food security is enormous. However, inadequate and extreme fluctuations in the amount of water available are major constraints to productivity and profitability of agriculture, making most poor farmers remain at subsistence level and in perpetual poverty (Hatibu et al., 2006). Given that water productivity in agriculture continues to be low, it is obvious that large volumes of water will be required to produce sufficient food for the increasing rural population. In view of the importance of the subject and the dearth of knowledge with regard to the level of adoption of rainwater harvesting technology (RWHT) in the study area, this study was undertaken to seek an understanding and explanation of the factors influencing rural households' rainwater harvesting adoption decisions.

\section{MATERIALS AND METHODS}

\section{Study area and data collection}

This study was conducted in Msinga, one of the four local municipalities constituting Umzinyathi District Municipality. It has 6 traditional authority areas, namely, Mchunu, Bomvu, Mabaso, Mthembu, Ngome, and Qamu, with a combined area of $2500 \mathrm{~km}^{2}$. The estimated population in 2007 was 161894 , with a total of 32592 households, of which only one-third of the population (about 53000 ) were economically active, resulting in a high unemployment rate in the area, with high-level involvement in subsistence and informal activities (Msinga Municipality, 2011). Msinga municipality is mostly rural; about $99 \%$ of its population lives in traditional areas. Agriculture is one of the most important economic sectors but it is still largely practised for subsistence, contributing only $18 \%$ of income. There is limited capacity of the land for productive agricultural development due to poor soil quality, adverse climatic conditions and soil erosion resulting from overgrazing. In general, the areas under extensive farming have erratic and unreliable rainfall (Msinga receives an average of $600-700 \mathrm{~mm} / \mathrm{a}$ ) and land degradation is very prevalent, this often fails to support rain-fed agriculture, resulting in persistent crop failures and subsequent food shortages in the area, making sustainable farming difficult. About $30 \%$ of the municipal area is made up of commercial farmland, with $70 \%$ of the land held in trust by the traditional authority - the Ingonyama Trust (Msinga Municipality, 2011). At present, 1967 ha of land is cultivated, of which 767 ha are under irrigation and with about 6800 ha of land having a potential for dry cropping. Numerous community garden clubs/ groups also cultivate vegetables on 89 ha of land, and these are predominantly located along available water sources (Msinga Municipality, 2011).

Multistage stratified random sampling was used to select representative households for the study (Barnett, 1991). In the first stage, a reconnaissance survey was conducted to identify and list households in the six traditional authority areas who had been exposed to RWHT, as well as those without such knowledge. Focus group discussions were used to obtained background information on adaptations as well as adoption of RWHT for home gardening. This information was used to design a structured questionnaire administered to respondents during the interview, which focused on their demographic and socio-economic characteristics, farming (home gardening), institutions, and the process of RWHT adoption. The second stage involved a random sampling of 180 households ( 30 respondent households from each of the six traditional authority areas), to obtain a representative sample of the whole community. About 126 sampled households had positive perceptions/attitudes towards RWHT and had adopted one form of rainwater harvesting technology or the other.

\section{Conceptual framework}

The theory of maximisation of utility is generally used to explain the response of farmers to adoption of a new technology (Greene, 2003). According to the theory, a new technology will be adopted by a farmer if the utility obtained from the new technology exceeds that of the former one. Following Adesina and Chianu (2002) and Sidibe (2005), it is assumed that a farmer's response to his situation is consistent with utility maximising. The utility a farmer obtains from the technology is represented by $U_{i j}$ with $j=(0,1)$ indicating the adoption or non-adoption of the technology and $i=(1,2, \ldots n)$ indexing the farmer's characteristics. Although these characteristics are not all observed, a linear relationship is assumed for the $i^{\text {th }}$ farmer between the utility derived from the $j^{\text {th }}$ technology and a vector of observed farmer's socio-economic characteristics $X_{i}$, and can then be represented as:

$$
U_{i j}=X_{i} a_{j}+\varepsilon_{j} j=0,1 \text { and } i=\{1,2, \ldots n\}
$$

The decision of the farmer is a process of two mutually 
exclusive alternatives: he either adopts $(j=1)$ or does not $(j=0)$. It is assume that a farmer chooses the option that gives him the largest utility. The $i^{\text {th }}$ farmer will adopt the technology $j$ if $U_{\mathrm{i} 1}>U_{\mathrm{io}}$ and the qualitative variable $D_{i}$ indexes the adoption decision. If $U_{\mathrm{i} 1} \leq U_{\mathrm{io}}$ then $D=0$ and $U_{\mathrm{i} 1}>U_{\mathrm{io}}$ then $D=1$. The probability of adoption of rainwater harvesting technology can then represented as follows:

$$
\begin{aligned}
\mathrm{P}_{\mathrm{r}} & =P_{r}\left(D_{i}=1\right)=P_{r}\left(U_{\mathrm{i} 1}>U_{\mathrm{i} 0}\right)=P_{r}\left(X_{\mathrm{i}} \alpha_{\mathrm{i} 1}+\varepsilon_{\mathrm{i} 1}>X_{\mathrm{i}} \alpha_{\mathrm{i} 0}+\varepsilon_{\mathrm{i} 0}\right) \\
& =P_{r}\left(\varepsilon_{\mathrm{i} 1}-\varepsilon_{\mathrm{i} 0}>X_{\mathrm{i}} \alpha_{\mathrm{i} 0}-X_{\mathrm{i} 1}\right)=P_{r}\left(\varepsilon_{\mathrm{i} 1}-\varepsilon_{\mathrm{i} 0}>X_{\mathrm{i}}\left(\alpha_{\mathrm{i} 0}-\alpha_{\mathrm{i} 1}\right)\right) \\
& =\operatorname{Pr}\left(\mu_{i}>X_{i} \beta\right)=F\left(X_{i} \beta\right)
\end{aligned}
$$

where:

$\mu_{i}=\left(\varepsilon_{\mathrm{i} 1}-\varepsilon_{\mathrm{i} 0}\right)$ and $F\left(X_{i} \beta\right)$ is the cumulative distribution function for $\mu_{i}$ estimated at $X_{i} \beta$.

The probability that a farmer will adopt rainwater harvesting technology is thus a function of the explanatory variables and the unknown error term. If $\mu_{i}$ is normal, then $F$ is the cumulative density function corresponding to the logistic model (Amemiya, 1981).

\section{The empirical model}

The logistic regression model was used to determine the factors that have significant influence on the adoption of RWHT in the study area. The model was chosen because it is a standard method of analysis when the outcome variable is dichotomous (Hosmer and Lemeshow, 2000), and when the adoption of agricultural technologies is measured as a dichotomous response variable having a value of 0 or 1 , where $0=$ non-adoption and $1=$ adoption of the innovation. There are 2 categories of storage reservoirs for RWHT considered for this study - surface or aboveground tanks (common for roof collection) and sub-surface or underground tanks (common for ground catchment systems). Households that have used either of the two categories of storage reservoirs for rainwater harvesting are classified as adopters of RWHT and those that have not as non-adopters.

If $X_{i}$ represents the set of parameters, including socioeconomic, farming, institutional factors and village-specific characteristics, which influence the adoption decisions of the $i^{\text {th }}$ farmer, then for the farmer $U_{i}$ is an indirect utility derived from the adoption decision, which is a linear function of $k$ explanatory variables $(X)$, and is expressed as:

$$
U_{i}=\beta_{0}+\sum_{i=1}^{n} \beta_{1} X_{k i}+\varepsilon
$$

where:

$\beta_{0}$ is the intercept term

$\beta_{1,} \beta_{2}, \beta_{3, \ldots} \beta_{i}$ are the coefficients associated with each explanatory variable $X_{1}, X_{2}, X_{3} \ldots X_{k i}$.

The RWHT adoption decision or the probability that the $i^{\text {th }}$ farmer adopts RWHT by the presence of these factors $\left(X_{i}\right)$ is given by:

$$
P_{i}=\frac{e^{U_{i}}}{1+e^{U_{i}}}
$$

where:

$P_{i}$ denotes the probability that the $i^{\text {th }}$ farmer's adoption decision is 1 , then $\left(1-P_{i}\right)$ is the probability that the adoption decision is 0 . The odds $(D=1$ versus $D=0)$ to be used can be defined as the ratio of the probability that a farmer adopts

$\left(P_{i}\right)$ to the probability of non-adoption $\left(1-P_{i}\right)$ i.e. $\frac{P_{i}}{1-P_{i}}$.

Taking the natural $\log$, the prediction equation for the $i^{\text {th }}$ farmer is expressed as:

$$
D=\ln \left(\frac{P_{i}}{1-P_{i}}\right)=\ln o d d s=\beta_{0}+\sum_{i=1}^{n} \beta_{i} X_{k i}+\varepsilon=U_{i}
$$

where:

$U_{i}$ is also referred to as the log of the odds ratio in favour of RWHT.

\section{Variables used in the empirical model}

Literature has shown that adoption of technology is determined by a host of factors, such as group participation (social capita), human capital (education), physical capital, land ownership, farm size, and contact with extension agents, as well as other household characteristics, which include age, household size, off-farm income, family income, etc. (see Ramji, et al., 2002; Abera, 2003; Chianu and Tsujii, 2004; Tassew, 2004; Sidibe, 2005). The explanatory variables used in the empirical logistic regression model are presented in Table 1.

\begin{tabular}{|l|l|c|}
\hline \multicolumn{2}{|c|}{ A priori expectations for the explanatory variables used in the Logit model } \\
\hline Variables & Definition and measurement & Expected signs \\
\hline Gender of household head & $D=1$ if male, 0 otherwise & + \\
\hline Age of household head & Age of household head in years & + \\
\hline Household head education & Number of years of formal education of household head & + \\
\hline Household size & Number of people in the household & + \\
\hline Household monthly income & Total household monthly income in Rands & + \\
\hline Off farm activity & $D=1$ if yes, 0 if otherwise & + \\
\hline Social capital & Number of associations belong to & + \\
\hline Contact with extension agent & Number of contact times in a year & + \\
\hline Security of land rights & $D=1$ if secured, 0 otherwise & + \\
\hline Access to farm inputs & $D=1$ if yes, 0 otherwise & $+/-$ \\
\hline Perception/Attitude toward RWHT & $D=1$ if feels it will have positive effect, 0 otherwise & - \\
\hline Distance to water tanks & Walking distance/time from water tanks to home garden (total minutes) & + \\
\hline Importance of livestock & Number of livestock (in LUs) & + \\
\hline
\end{tabular}

Based on a priori expectations 


\section{RESULTS AND DISCUSSION}

\section{Socio-economic characteristics of the respondent households}

Households' demographic, socio-economic and farm characteristics play an important role in determining their technology adoption decisions and their livelihoods. The majority (77\%) of the farmers were male. The average age of the farmers was 40 years, indicating that majority of the respondents were within the active and productive age range.

The level of education determines the level of opportunities available to improve livelihood strategies and managerial capability in production. The study revealed that about $64 \%$ of the farmers were educated, while about $36 \%$ had no formal education. As practised in many rural economies in developing countries, farming is the major source of livelihood for the households in the study area. About $75 \%$ of the respondents were either crop or livestock farmers. The average household size was 8 persons. Large family size is not uncommon with subsistence agriculture as it is required to meet the labour requirement on the farm.

The average household monthly income was R775. The majority of the households had no access to formal credit facilities. Only $15 \%$ of farmers had access to credit facilities, while the majority depended on their personal savings to finance their farm operations. Most households reported participating in a variety of groups. Group participation facilitates the spread of knowledge, information and innovations. Households belong to an average of 3 groups, with 2 types predominating, i.e., financial groups, which includes stokvels (saving clubs) and burial societies (which provide insurance for funeral costs), and religious groups. A household had at least one contact with an extension agent in a year. About $38 \%$ of the households reported between 1 and 3 extension contacts in a year.

Security of land rights is of great importance to farmers especially in rural areas due to land scarcity. The ease of acquiring farm lands bears direct relationship with the hectares cultivated by the farmer, vis-à-vis his output. The majority of the famers felt that their land rights are not secured. This is because land is not owned by individuals but held in trust by the ingonyama (King) who distributes it to district chiefs. It is usually the chiefs and their indunas (headmen) who allocate land to household heads.
The majority of the farmers had a positive attitude towards the rainwater harvesting technology; however, about $30 \%$ of them did not. The lack of capital and credit, and the labourintensive nature of the technology are the reasons given for their negative perception of the technology. The statistics of the explanatory variables and the distribution of the households' socio-economic characteristics are presented in Tables 2 and 3, respectively.

\section{The empirical result of the logistic regression model}

The maximum likelihood method using the SPSS 17.0 was used to estimate the coefficients of the binary logistic regression of the factors influencing the adoption of RWHT. The model fit was tested using the Hosmer and Lemeshow statistics. The overall percentage of correct predictions was $89.2 \%$. The $p$-value of 0.721 shows that there is a significant difference between the observed and predicted values of the dependent variables, indicating that the model's estimates fit the data well, at an acceptable level. The binary logistic regression estimates and the exponential of the logistic regression estimate (which is interpreted as the predicted change in odds for unit increase in the corresponding variable) are presented in Table 4.

The results presented in Table 4 show a statistically-significant positive relationship between gender and adoption of rainwater harvesting technology. The odds ratio for gender is 3.490, implying that a male farmer is more likely to adopt RWHT, at 3.5 times the odds of a female farmer. This finding is consistent with a priori expectations, and may be a reflection of the bias against rural women inheriting land or having secure land rights. Previous adoption studies have found that women are less likely to adopt new technology (Adesina and Chianu, 2002).

Age has a statistically significant negative effect on adoption of RWHT, i.e., older farmers are less likely to adopt RWHT. The odds ratio for age is 0.966 , implying that a year increase in the age of farmer decreases the probability of adoption by about 1. This is consistent with the theory of human capital; young members of a household have a greater chance of absorbing and applying new knowledge (Sidibe, 2005).

Education has a statistically-significant positive effect on adoption of RWHT, i.e., educated farmers are more likely to adopt RWHT. The odds ratio for education is 1.26 , implying that one more year of education increases the probability of adoption of RWHT by 1.26. This is consistent with the findings

\begin{tabular}{|l|c|c|c|c|}
\hline \multicolumn{5}{|c|}{ TABLE 2 } \\
Statistics of the explanatory variables used in the empirical logistic model \\
\hline Variables & Min & Max & Mean & S.D \\
\hline Gender & 0 & 1 & 0.65 & 0.478 \\
\hline Age of household head & 25 & 76 & 40.37 & 11.97 \\
\hline Household head education & 0 & 4 & 1.83 & 0.99 \\
\hline Household size & 5 & 24 & 8.2 & 4.65 \\
\hline Household monthly income & 525 & 2750 & 775 & 1250 \\
\hline Off-farm activity & 0 & 1 & 0.25 & 0.315 \\
\hline Social capital & 0 & 3 & 2.67 & 0.488 \\
\hline Contact with extension & 0 & 4 & 1.25 & 0.432 \\
\hline Security of land rights & 0 & 1 & 0.31 & 0.213 \\
\hline Access to farm input & 0 & 1 & 0.72 & 0.531 \\
\hline Perception/attitude toward RWHT & 0 & 1 & 0.70 & 0.210 \\
\hline Distance to water tanks & 1 & 15 & 6.85 & 5.341 \\
\hline Importance of livestock & 4 & 25 & 1.34 & 0.478 \\
\hline
\end{tabular}

Source: Calculated from field survey data. 


\begin{tabular}{|c|c|c|}
\hline \multicolumn{3}{|c|}{$\begin{array}{c}\text { TABLE } 3 \\
\begin{array}{c}\text { Distribution of farmers based on socio-economic } \\
\text { characteristics }(n=180)\end{array} \\
\end{array}$} \\
\hline Socio-economic characteristics & (n) & $\begin{array}{l}\text { Percen- } \\
\text { tage (\%) }\end{array}$ \\
\hline \multicolumn{3}{|l|}{ Gender of farmer: } \\
\hline Male & 139 & 77 \\
\hline Female & 41 & 23 \\
\hline \multicolumn{3}{|l|}{ Age: } \\
\hline $20-39$ & 59 & 33 \\
\hline $40-59$ & 104 & 58 \\
\hline $60-69$ & 17 & 9 \\
\hline \multicolumn{3}{|l|}{ Education: } \\
\hline No formal education & 65 & 36 \\
\hline Primary ( $1-5$ years of schooling) & 38 & 21 \\
\hline Middle (6-9 years of schooling) & 43 & 24 \\
\hline Matric and above ( $10+$ years of schooling) & 34 & 19 \\
\hline \multicolumn{3}{|l|}{ Family size: } \\
\hline $1-10$ & 133 & 74 \\
\hline $11-20$ & 40 & 22 \\
\hline$>20$ & 7 & 4 \\
\hline \multicolumn{3}{|l|}{ Household monthly income (in Rands): } \\
\hline $500-1499$ & 136 & 76 \\
\hline $1500-2499$ & 18 & 10 \\
\hline 2500 & 26 & 14 \\
\hline \multicolumn{3}{|l|}{ Major occupation: } \\
\hline Farming & 135 & 75 \\
\hline Other & 45 & 25 \\
\hline \multicolumn{3}{|c|}{ Social capital (Number of groups/associations belongs to): } \\
\hline 0 & 34 & 19 \\
\hline $1-2$ & 130 & 27 \\
\hline$>2$ & 16 & 9 \\
\hline \multicolumn{3}{|l|}{ Contact with extension agent: } \\
\hline 0 & 33 & 22 \\
\hline $1-3$ & 82 & 54 \\
\hline$>3$ & 25 & 16 \\
\hline \multicolumn{3}{|l|}{ Source of capital: } \\
\hline Loan/credit & 27 & 15 \\
\hline Personal savings & 153 & 85 \\
\hline \multicolumn{3}{|l|}{ Security of land rights: } \\
\hline Feel secured & 56 & 31 \\
\hline Not secured & 124 & 69 \\
\hline \multicolumn{3}{|l|}{ Perception/attitude toward RWHT: } \\
\hline Positive & 126 & 70 \\
\hline Negative & 54 & 30 \\
\hline
\end{tabular}

of Chianu and Tsujii (2004), Sidibe (2005) and He et al. (2007). Education improves the capability for resourcefulness and invention.

Household income has a statistically-significant positive effect on adoption of RWHT, i.e. ,farmers with higher family incomes are more likely to adopt RWHT. The odds ratio for income is 3.38, implying that an increase in households' income increases the probability of adoption of RWHT by 3.38 . A higher level of household income implies a greater incentive for investment in agricultural technologies and ability to bear the risk associated with its adoption.

Social capital has a statistically-significant positive effect on adoption of RWHT, i.e., farmers who are members of associations/groups are more likely to adopt RWHT. The odds ratio for social capital is 7.149, implying that association/group membership increases the probability of adoption of RWHT by 7.149. Participation in group activities and being connected to social systems proved to be positively associated with early adoption of technologies (Birungi and Hassan, 2007; Katungi, et al., 2007). The higher the degree of connectedness of a community the more easily people would be able to transfer information and the more people this information is likely to reach (Baiyegunhi, 2013).

Contact with extension has a statistically-significant positive effect on adoption of RWHT, i.e., farmers who had contact with extension agents/experts are more likely to adopt RWHT. The odds ratio for extension contact is 2.83 , implying that one more contact with extension agents increases the probability of adoption of RWHT by 2.83. Contact with extension agents allows farmers greater access to information, training on technology, inputs, credit and the borrowing of agricultural equipment, through increased opportunities to participate in on-farm demonstrations and trials, which thus increase farmers' ability to adopt RWHT (Adesina and Chianu, 2002; Sidibe, 2005).

Security of land rights has a statistically-significant positive effect on adoption of RWHT, i.e., farmers who feel their land rights are secured are more likely to adopt RWHT. The odds ratio for security of land rights is 3.47 , implying a secured land right could increase the probability of adoption of RWHT by 3.47. In most rural areas of South Africa, land is not owned by individuals but held in trust by the ingonyama (King) who distributes it to district chiefs. It is usually the chiefs and their indunas (headmen) who allocate land to household heads. The

Source: Calculated from field survey data.

\begin{tabular}{|c|c|c|c|c|}
\hline Parameter estimates of the bin & $\begin{array}{r}\mathrm{TAB} \\
\text { ogit moc }\end{array}$ & factors & sencing adop & of RWHT \\
\hline Variables & B & SE & Significance & $\operatorname{Exp}(\beta)$ \\
\hline Gender & 1.250 & 0.748 & $0.095^{*}$ & 3.490 \\
\hline Age of household head & -0.035 & 0.023 & $0.018^{* *}$ & 0.966 \\
\hline Household head education & 0.232 & 0.133 & $0.094^{*}$ & 1.261 \\
\hline Household size & 0.016 & 0.029 & 0.957 & 1.016 \\
\hline Household income & 1.175 & 0.537 & $0.003^{* *+}$ & 3.238 \\
\hline Off-farm activity & 0.034 & 0.330 & 0.305 & 1.034 \\
\hline Social capital & 1.967 & 0.585 & $0.001^{x * x}$ & 7.149 \\
\hline Contact with extension & 1.040 & 2.095 & $0.016^{* *}$ & 2.829 \\
\hline Security of land rights & 1.245 & 0.648 & $0.012^{* *}$ & 3.472 \\
\hline Access to farm input & 0.499 & 0.853 & 0.323 & 1.647 \\
\hline Perception/attitude toward RWHT & 1.082 & 0.695 & $0.002^{* * *}$ & 2.950 \\
\hline Distance to water tanks & -0.395 & 0.432 & 0.973 & 0.673 \\
\hline Importance of livestock & 0.056 & 0.508 & 0.754 & 1.057 \\
\hline Constant & -0.986 & 1.530 & 0.520 & 0.373 \\
\hline $\begin{array}{l}\text { Number of observation: } 180 \text {; Hosme } \\
-2 \log \text { likelihood }=84.67 ; \text { Nagelkerk }\end{array}$ & $\begin{array}{l}\mathrm{d} \text { Lemesh } \\
=0.78 ; \mathrm{Ov}\end{array}$ & $\begin{array}{l}\text { Chi }{ }^{2}=3 \\
\operatorname{aracy}\end{array}$ & $\begin{array}{l}\text { d.f }=8 \text {; Sign } \\
\text { ly predicte }\end{array}$ & $2 \%$ \\
\hline
\end{tabular}


fear of losing land due to land redistribution gives farmers a sense of insecurity, which often discourages them from investing in fixed improvements on their land (Bekele and Drake 2003).

Farmer's perception/attitude toward RWHT has a statistically-significant positive effect on adoption of RWHT, i.e., farmers who have positive perceptions/attitude towards RWHT are more likely to adopt it. The odds ratio for perceptions/attitude is 2.95 , implying that a famer who has a positive attitude is likely to adopt RWHT at 3 times the odds of a farmer who has a negative attitude. This result is not surprising and is consistent with a priori expectations and the findings of $\mathrm{He}$ et al. (2007). A positive perception/attitude towards an innovation by a household is expected to lead to subsequent adoption of such technology.

\section{CONCLUSION AND POLICY IMPLICATIONS}

The aim of this study was to determine the factors influencing households' adoption of rainwater harvesting technology (RWHT) for home gardening in Msinga, KwaZulu-Natal. Useful findings have emerged that provide insight into the pathways to increase the adoption of RWHT. The result of the logistic regression model indicates that gender, age, education, income, social capital, contact with extension agent and perception/attitude towards RWHT are statistically significant in explaining farmers' adoption of RWHT in the study area.

Therefore, there is a need for policy makers and the private sector to target young farmers when promoting adoption. Increasing rural farmers' educational attainment can increase the probability of agricultural technology adoption. The finding that male farmers have a higher likelihood of adopting RWHT than female farmers suggests the need to develop more appropriate options for women. Women form the majority of farm labour but suffer several constraints to the use of sustainable agricultural practices and household resources. Efforts are needed to reduce the gender gap in the adoption of RWHT.

There is also a need for improvement in farmers' contact and access to extension services. The present situation in which farmers have an average of 1 extension contact in a year is detrimental. Improved access and contact with extension agents could increase farmers' knowledge and perception of the benefit of RWHT through better access to technical information, education and training. Furthermore, there is a need for greater social capital formation through group membership/ networks. Government, the private sector and extension agents could also enhance technology adoption appropriately with a better understanding of the nature and objectives of the existing social groups/networks in rural areas, in order to use them for project design and delivery. Security of land rights also needs to be improved for adoption of new farming technologies and increased agricultural productivity, which could translate into higher incomes for rural farmers.

\section{REFERENCES}

ABERA BD (2003) Factors influencing the adoption of soil conservation practices in Northwestern Ethiopia. Discussion Paper No. 37. Institute of Rural Development, University of Goettingen, Goettingen, Germany.

ACTION AID (2005) Food security and HIV and AIDS in Southern Africa: case studies and implications for future policy. Action Aid International Southern Africa Partnership Programme, Johannesburg. URL: www.sarpn.org/documents/.../Food-security Oct2005 Full-report.pdf (Accessed 19 November 2013).
ADESINA AA and CHIANU J (2002) Determinants of farmers' adoption and adaptation of alley farming technology in Nigeria. Agrofor. Syst. 55 99-112.

AMEMIYA T (1981) Qualitative response models: a survey. J. Econ. Lit. $191483-1536$.

BAIPHETHI MN, VILJOEN MF, KUNDHLANDE G, BOTHA JJ and van RENSBURG LD (2006) Quantifying the impact of in-field rainwater harvesting (IRWH) production techniques on household food security for communal farmers in Thaba Nchu, Free State Province. Agrekon 45 (3) 279-293.

BAIYEGUNHI LJS (2013) Rural households' social capital and welfare: A case study of Msinga, KwaZulu-Natal, South Africa. J. Agric. Rural Dev. Trop. Subtrop. 114 (2) 123-132.

BARNETT V (1991) Sample Survey: Principles and Methods. Edward Arnold, London.

BEKELE W and DRAKE L (2003) Soil and water conservation decision behaviour of subsistence farmers in the Eastern Highlands of Ethiopia: a case study of the Hunde-Lafto area. Ecol. Econ. 46 437-451.

BIRUNGI P and HASSAN R (2007) Impact of alternative land management options on soil fertility and erosion in Uganda. Agrekon 46 (3) $410-424$.

BOERS TM (1994) Rainwater Harvesting in Arid and Semi-Arid Zones. International Institute for Land Reclamation and Improvement, Wageningen.

BULCOOK LM and SCHULZE RE (2011) Climate change and a case study in rainwater harvesting: A 2011 perspective. In: Schulze RE (ed.) A 2011 perspective on climate change and the South African water sector. WRC Report 1843/2/11. Water Research Commission, Pretoria.

CHIANU JN and TSUJII H (2004) Determinants of farmers' decision to adopt or not adopt inorganic fertilizer in the savannas of northern Nigeria. Nutr. Cycl. Agroecosyst. 70 (3) 293-301.

DEPARTMENT OF HEALTH (SOUTH AFRICA) (2006) Social cluster: parliamentary media briefing, presented by the Minister of Health, Dr Manto Tshabalala-Msimang on behalf of the social cluster. URL: http://www.info.gov.za/speeches/2006/06021015451002. htm (Accessed 8 September 2013).

DWAF (DEPARTMENT OF WATER AFFAIRS AND FORESTY, SOUTH AFRICA) (1994) Water Supply and Sanitation Policy White Paper. Water - An Indivisible National Asset. Department of Water Affairs and Forestry, Pretoria.

FAO (2001) State of Food Insecurity. Food and Agriculture Organization of the United Nations, Rome.

GALHENA DH, FREED R and MAREDIA KM (2013) Home gardens: a promising approach to enhance household food security and wellbeing. Agric. Food Secur. 2 (8) 1-13.

GREENE WH (2003) Econometric Analysis (5 ${ }^{\text {th }}$ edn.). Prentice-Hall, Upper Saddle River, NJ.

HATIBU N, MUTABAZI K, SEKONDO EM and MSANGI ASK (2006) Economics of rainwater harvesting for crop enterprises in semiarid areas of East Africa. Agric. Water Manage. 80 (1-3) 74-86.

HE X, CAO H and LI F (2007) Econometric analysis of the determinants of adoption of rainwater harvesting and supplementary irrigation technology in the semi-arid loess Plateau of China. Agric. Water Manage. 89 243-250.

HSRC (2003) Mitigation of HIV and AIDS impact through agricultural and rural development, success stories and future action. Human Science Resources Council Workshop Report, 27-29 May 2003, Pretoria. URL: http://www.sarpn.org/mitigation of HIV AIDS/ Mitigation of HIV-AIDS Report.pdf (Accessed 8 October 2012)

HOSMER D and LEMESHOW S (2000) Applied Logistic Regression ( ${ }^{\text {rd }}$ edn). Wiley-Interscience, New York.

KATUNGI E, MACHETHE C and SMALE M (2007) Determinants of social capital in rural Uganda: Implications for group-based agricultural extension approaches. Afr. J. Agric. Resour. Econ. 1 (2) 166-190.

LIU JG, FRITZ S, VAN WESENBEECK CFA, FUCHS M, YOU LZ, OBERSTEINER M and YANG H (2008) A spatially explicit assessment of current and future hotspots of hunger in Sub-Saharan Africa in the context of global change. Global Planet. Change $\mathbf{6 4}$ 222-235. 
MBILINYI BP, TUMBO, SD, MAHOO HF, SENKONDO EM and HATIBU N (2005) Indigenous knowledge as decision support tool in rainwater harvesting. Phys. Chem. Earth 30 792-798.

MOLDEN D (ed.) (2007) Water for Food, Water for Life: A Comprehensive Assessment of Water Management in Agriculture. Earthscan, London.

MOORHEAD S and WOLMER W (2001) Food security and environment. In M Devereux (ed.) Food Security in Sub-Saharan Africa. Institute of Development Studies, University of Sussex, Brighton. ITDG Publishers, London. 93-116.

MSINGA MUNICIPALITY (2011) Msinga Integrated Development Plan 2011/2012. URL: http://devplan.kzntl.gov.za/idp reviewed 2011 12/IDPS/KZ244/Adopted/Msinga\%20\%20IDP\%20 2011.12\%20.pdf (Accessed 25 May 2012).

MWENGE-KAHINDA J, BOROTO RJ and TAIGBENU AE (2005) Developing an integrated water resources management and rainwater harvesting systems in South Africa. Paper presented at: $12^{\text {th }}$ SANCIAHS Symposium, 5-7 September 2005, Johannesburg.

MWENGE-KAHINDA J, TAIGBENU AE and BOROTO RJ (2005) Domestic rainwater harvesting to improve water supply in rural South Africa. Phys. Chem. Earth 32 1050-1057.

NAIR PKR (1993) An Introduction to Agroforestry. Kluwer Academic Publishers. Dordrecht, London.

NDA (NATIONAL DEPARTMENT OF AGRICULTURE, SOUTH AFRICA) (2007) Agricultural Statistics. National Department of Agriculture, Pretoria. URL: www.nda.agric.za/docs/statsinfo/ Ab2007.pdf (Accessed 15 October 2013).

ODEBODE OS (2006) Assessment of home gardening as a potential source of household income in Akinyele Local Government Area of Oyo State. Nigerian J. Hortic. Sci. 2 47-55.

OTIENO FAO and OCHIENG GMM (2004) Water management tools as a means of averting a possible water scarcity in South Africa by the year 2025. Water SA 30 (5) 120-124.

OWEIS T, HACHUM A and KILNE J (1999) Water harvesting and supplemental irrigation for improved water use efficiency in dry areas. SWIM paper No.7. International Water Management Institute, Colombo, Sri Lanka.
OWEIS T and HACHUM A (2006) Water harvesting and supplemental irrigation for improved water productivity of dry farming systems in West Asia and North Africa. Agric. Water Manage. 80 57-73.

PEYRE A, GUIDAL A, WIERSUM KF and BONGERS F (2006) Dynamics of home gardens structure and functions in Kerala, India. Agrofor. Syst. 66 101-115.

RAMJI P, NEUPANE KR and SHARMA GBT (2002) Adoption of agroforesty in the hills of Nepal: a logistic regression analysis. Agric. Syst. 72 177-196.

ROCKSTRÖM J (2000) Water resources management in smallholder farms in Eastern and Southern Africa: An overview. Phys. Chem. Earth 25 (3) 275-283.

SIDIBE A (2005) Farm-level adoption of soil and water conservation techniques in Northern Burkina Faso. Agric. Water Manage. 71 211-224.

SIEGERT K (1994) Introduction to water harvesting: some basic principles for planning, design, and monitoring water harvesting for improved agricultural production. Proceedings of the FAO Expert Consultation, Cairo, 21-25 November 1993. FAO, Rome.

SIGOT AJ (2001) Indigenous food systems: creating and promoting sustainable livelihoods. Proceedings of the International Conference on Indigenous Knowledge Systems: African Perspectives, 12-15 September 2001, Thohoyandou, South Africa.

SPSS Inc. (2011) SPSS Statistics 17.0. SPSS Inc., Chicago, Illinois. USA.

TASSEW W (2004) The role of schooling in the alleviation of rural poverty in Ethiopia. In: Proceedings of $25^{\text {th }}$ International Conference of Agricultural Economists (IAAE) 16-22 August 2003, Durban, South Africa.

VINK N and KIRSTEN J (2003) Agriculture in the national economy. In: Nieuwoudt L and Groenewald J (eds) The Challenge of Change: Agriculture, Land and The South African Economy. Natal University Press, Pietermaritzburg. 1-19.

ZHOU Y, ZHANG Y, ABBASPOUR CK, YANG H and MOSLER JH (2009) Economic impacts on farm households due to water reallocation in China's Chaobai watershed. Agric. Water Manage. 96 883-891. 
http://dx.doi.org/10.4314/wsa.v41i1.6 Available on website http://www.wrc.org.za

ISSN 0378-4738 (Print) = Water SA Vol. 41 No. 1 January 2015 ISSN 1816-7950 (On-line) = Water SA Vol. 41 No. 1 January 2015 